\title{
Antioxidant capacity of snack cookies made from mango and pineapple fermentation
}

\author{
${ }^{1}$ Rompies, R., ${ }^{1}$ Mayulu, N., ${ }^{2, *}$ Nurkolis, F., ${ }^{3}$ Faradila, F., ${ }^{1}$ Kepel, B.J. and ${ }^{1}$ Natanael, H. \\ ${ }^{1}$ Faculty of Medicine, Sam Ratulangi University, Manado, Indonesia \\ ${ }^{2}$ Biological Sciences, Faculty of Sciences dan Technology, State Islamic University of Sunan Kalijaga, \\ Yogyakarta, Indonesia \\ ${ }^{3}$ Faculty of Medicine, Andalas University, Padang, Indonesia
}

\begin{abstract}
Article history:
Received: 30 January 2021

Received in revised form: 22

March 2021

Accepted: 22 May 2021

Available Online: 26

September 2021
\end{abstract}

\section{Keywords:}

Antioxidants,

Cookies,

Mango,

Pineapple,

Vitamin C

\section{DOI:}

https://doi.org/10.26656/fr.2017.5(5).010
Abstract

Mango (Mangifera indica) and pineapple (Ananas Comosus) are tropical fruits that contain many nutrients, one of which is antioxidants and polyphenols. Lots of studies have shown that fermented fruit is higher in antioxidants and health benefits. Antioxidants have been reported to be an alternative to enhance body immunity and possibly become an Anti -SARS-CoV-2. One of the antioxidants that are easily found in vitamin C. This study is to process the fermented mango and pineapple fruits into cookies and to test the antioxidant content (especially Vitamin C) in vitro. There were three variations of the formulation, mango: pineapple: $\mathrm{CO}_{2}$ free water. Sample 1 (1: 0.5: 0.5), sample 2 (2: 1: 1) and sample 3 (3: 2: 2). Then, all product samples were inoculated with Lactobacillus paracasei $5 \% \mathrm{~b} / \mathrm{v}$ for 14 days under anaerobic conditions to get simpler mangoes and pineapple food fibre. The fermented products were made into flour with a freeze dryer. Sample variation is done to determine the average significance of the antioxidant content in it. The next step was Vitamin $\mathrm{C}$ analysis from 3 samples of cookies sample using Titration Iodometric Method, to determine the amount of Vitamin C (mg/100 g) and also the antioxidant activity with 2,2-diphenyl-1-picrylhydrazyl (DPPH). The amount of vitamin C obtained in Sample 1 was $100.20 \mathrm{mg} / 100 \mathrm{~g}$ respectively with antioxidant activity is $35.33 \%$. Sample 2 was $95.75 \mathrm{mg} / 100 \mathrm{~g}$ respectively with antioxidant activity is $30.60 \%$. Sample 3 was $107.90 \mathrm{mg} / 100 \mathrm{~g}$ respectively with antioxidant activity is $44.70 \%$. The formulation with the highest amount of cookies sample containing vitamin $\mathrm{C}$ is $\mathrm{S} 3$. There was a significant difference $(\mathrm{P}<0.05)$ that determined vitamin $\mathrm{C}$ levels between sample formulations. The mean ash content of the three samples was $2.02 \pm 0.04 \%$ and water content were $1.60 \pm$ $0.15 \%$. The average vitamin $\mathrm{C}$ levels in the three sample cookies were $101.28 \pm 6.14$ $\mathrm{mg} / 100 \mathrm{~g}$. Sample 3 indicated the best antioxidant activity towards 2,2-diphenyl-1picrylhydrazyl (DPPH) in the amount of $44.70 \%$. Therefore, fermented mango and pineapple have a great potential to be developed into healthy snack cookies. The vitamin $\mathrm{C}$ and antioxidants content in cookies from the fermentation of mango and pineapple may be a great substitute for snacks since antioxidants has the ability to improve immunity and anti-inflammatory response. These cookies are also good prebiotics for the gut microbiome which plays a good role in the immune system.

\section{Introduction}

Mango (Mangifera indica) is a tropical fruit plant that contains high levels of nutrients, fibre, macronutrients, micronutrients and minerals as well as abundant bioactive compounds (Maldonado-Celis et al., 2019). The well-known high content in mangoes, including vitamin $\mathrm{C}$, beta-carotene, polyphenol types of quercetin and kaempferol (Nurkolis et al., 2020; Mantik et al., 2021). Likewise, pineapple fruit (Ananas comosus) which is included in tropical fruit, is rich in nutrients and minerals, such as vitamin $\mathrm{C}$, dietary fibre especially the bromelain enzyme (Arampath and Dekker, 2019). Both of these fruits contain a lot of dietary fibre which can be processed into functional foods such as fermentation drinks or probiotic drinks. The fermentation process is known to increase the levels of antioxidants or vitamin C in processed food products (Selibata et al., 2017). Lots of 
studies have shown that fermented fruit is higher in antioxidants and health benefits (Gagnon et al., 2015). Recent research has shown that increasing the intake of foods high in antioxidants and polyphenols such as Vitamin C, beta-carotene, quercetin and kaempferol can increase the body immunity against viral infection (Levy et al., 2020; Pitsillou et al., 2020; Suhail et al., 2020). The addition of pineapple in previous studies has shown that it can increase antioxidant levels in yogurt products (Kusumawati et al., 2020). By looking at the potential based on the basis of previous research, mangoes and pineapples can be used as fermentation drinks and other processed products, which has the potential to increase body immunity. In this study, researchers made processed products based on pineapple and mango fruit which were fermented with the Lactobacillus paracasei to get simpler mangoes and pineapples food fibre.

\section{Material and methods}

There were 3 variations of the formulation, mango: pineapple: $\mathrm{CO}_{2}$ free water. Sample 1 (S1), 1: 0.5: 0.5, sample 2 (S2), 2: 1: 1 and sample 3 (S3), 3: 2: 2. Then, all product samples were inoculated with Lactobacillus paracasei $5 \%$ b/v for 14 days under anaerobic conditions. The part of mangoes and pineapples used were pure ripe flesh. The fermented products were made into flour with a freeze dryer, then the powder was mixed and stirred with the addition of $5 \%$ water using a mixer with a power of 102-189 rpm for $30 \mathrm{mins}$ and then put in the oven for 15 mins with a temperature of $70-90$ ${ }^{\circ} \mathrm{C}$ so that it became cookies. Sample variation was done to determine the average significance of the antioxidant content in it.

\subsection{Vitamin C analysis}

The next step was Vitamin $\mathrm{C}$ analysis from 3 samples of cookies sample using Titration Iodometric Method, to determine the amount of Vitamin C (mg/100 g) and also the antioxidant activity with 2,2-diphenyl-1picrylhydrazyl (DPPH).

$$
\text { Vitamin C }\left(\frac{\mathrm{mg}}{100 \mathrm{~g}}\right)=\frac{\mathrm{VI} 2 \times 0.88 \times \mathrm{Fp} \times 100}{\text { Ws gram }}
$$

Where V I2 = Iodine Volume $(\mathrm{mL}), \mathrm{Fp}=$ Dilution Factor, Ws $=$ Sample weight (grams) and $0.88=0.88 \mathrm{mg}$ of ascorbic acid is equivalent to $1 \mathrm{~mL}$ of I2 $0.01 \mathrm{~N}$ solution

\subsection{Water content analysis}

The determination of water content used was the AOAC drying method (Thermogravimetry). The principle of this method is based on the evaporation of water in the material by heating, then weighing it to a constant weight. The weight reduction that occurs is the water content contained in the material. The way these method works is an empty plate heated in an oven at $105^{\circ} \mathrm{C}$ for 30 mins, cooled down in a desiccator for 15 mins, then weighed (W0). Approximately $2 \mathrm{~g}$ sample was then put in a plate with known weight, weighed (W1), then dried in an oven at $105^{\circ} \mathrm{C}$ for $3 \mathrm{hrs}$, cooled in a desiccator for 15-30 mins, then the plates and contents were weighed and dried again for another one hour, cooled in the exicator, and weighed again (W2). The water content was calculated using the following formula:

$$
\text { Water content }(\%)=\frac{\mathrm{W} 1-\mathrm{W} 2}{\mathrm{~W} 1-\mathrm{W} 0} \times 100
$$

Where $\mathrm{W} 0=$ sample weight before drying (grams), W1 = weight of sample and dry cup (grams) and W2 = empty cup weight (grams)

\subsection{Ash content analysis}

The procedure for determining the ash content was carried out using the AOAC (2005) method. Meanwhile, the procedure is as follows: the cup was dried in an oven at $105^{\circ} \mathrm{C}$ for $1 \mathrm{hr}$. Then, it was cooled in the cup for 15 mins in a desiccator and weighed. Approximately, $2 \mathrm{~g}$ of the sample was put into a furnace where the temperature was $550^{\circ} \mathrm{C}$ for $3 \mathrm{hrs}$. It was then cooled outside the furnace to a temperature of $120^{\circ} \mathrm{C}$ and put in a desiccator. The plates and ashes were weighed so that a constant weight was obtained. Calculation of the ash content was carried out using the following formula:

Ash content $(\%)=\frac{\text { Weight of bowl after heated }- \text { constant weight of empty bowl }}{\text { Sample Weight }} \times 100$

\section{Results and discussion}

The results of vitamin $\mathrm{C}$ and antioxidant activity in each sample of fermentation before the cookies processing; S1 was $107.63 \mathrm{mg} / 100 \mathrm{~g}$ with $38.52 \%$ antioxidant activity, S2 was $98.21 \mathrm{mg} / 100 \mathrm{~g}$ with $34.83 \%$ of antioxidant activity and S3 was 111.16 $\mathrm{mg} / 100 \mathrm{~g}$ with $48.12 \%$ antioxidant activity. And after the cookies processing, the amount of vitamin $\mathrm{C}$ obtained in $\mathrm{S} 1$ was $100.20 \mathrm{mg} / 100 \mathrm{~g}$ with $35.33 \%$ antioxidant activity, S2 was $95.75 \mathrm{mg} / 100 \mathrm{~g}$ with $30.60 \%$ of antioxidant activity and S3 was $107.90 \mathrm{mg} / 100 \mathrm{~g}$ with $44.70 \%$ antioxidant activity (Table 1). The formulation for the number of cookies samples containing the highest vitamin $\mathrm{C}$ was $\mathrm{S} 3$. There was a significant difference $(\mathrm{P}<0.05)$ which determined the vitamin $\mathrm{C}$ level between the sample formulations. The higher the antioxidant activity, the higher the antioxidant levels, and the less food needed to reduce free radicals (Lisdawati and Kardono, 2012). This shows that the formulation of a blend of fermented pineapple and mango which was made into cookies contain vitamin $\mathrm{C}$ and has antioxidant activity. Foods that are high in antioxidants and vitamin $\mathrm{C}$ can act as immunomodulators and even help the 
Table 1. Vitamin C content, anti-oxidant activity, water and ash content in cookies sample.

\begin{tabular}{ccccc}
\hline Sample & $\begin{array}{c}\text { Vitamin C Content } \\
(\mathrm{mg} / 100 \mathrm{~g})\end{array}$ & $\begin{array}{c}\text { Anti-oxidant activity } \\
(\% \mathrm{DPPH})\end{array}$ & $\begin{array}{c}\text { Ash Content } \\
(\%)\end{array}$ & $\begin{array}{c}\text { Water Content } \\
(\%)\end{array}$ \\
\hline S1 & 100.20 & 35.33 & 1.97 & 1.77 \\
S2 & 95.75 & 30.60 & 2.05 & 1.55 \\
S3 & 107.90 & 44.70 & 2.04 & 1.48 \\
Mean & $101.28 \pm 6.14$ & $18.43 \pm 7.17$ & $2.02 \pm 0.04$ & $1.60 \pm 0.15$ \\
\hline
\end{tabular}

process of T-cell maturation (Manning et al., 2013). This makes formulated cookies a potential healthy snack that is high in vitamin $\mathrm{C}$ and antioxidants during the COVID19 pandemic. The average vitamin $\mathrm{C}$ level in the three cookie samples was $101.28 \mathrm{mg} / 100 \mathrm{~g}$. S3 showed the best activity, namely antioxidant activity against 2,2diphenyl-1-picrylhydrazyl (DPPH) of $44.70 \%$ (Table 1).

The average ash content of the three samples was $2.02 \%$ and water content was $1.60 \%$ which is in accordance with the Indonesian National Standard (SNI) 01-2973-1992. In accordance with research (Andarwulan et al., 2014) which stated that the higher the ash content in cookies indicates the higher mineral contents in cookies such as calcium, potassium, and iron. It is clinically known that mineral intake can improve the respiratory system, especially in tuberculosis sufferers (Taslim et al., 2020).

Fermented mango and pineapple have a great potential to be developed into healthy snack cookies. The vitamin $\mathrm{C}$ and antioxidants content in cookies from the fermentation of mango and pineapple may be a great substitute for snacks during the pandemic since antioxidants and vitamin $\mathrm{C}$ have the ability to improve immunity and anti-inflammatory response. These cookies are also good prebiotics for the gut microbiome which plays a good role in the immune system. It needs clinical trials in humans to find out more about its effects on human health and the authors are very open to joint research collaborations.

\section{Conflict of interest}

The authors declare no conflicts of interest.

\section{Acknowledgments}

We thank the State Islamic University of Sunan Kalijaga with Faculty of Medicine, Sam Ratulangi University and all of the contributors for their outstanding help in formatting the paper.

\section{References}

Andarwulan, N., Kusnandar, F. and Herawati, D. (2014). Pengelolaan Dara Analisis Pangan. Modul I. Retrieved from website: http:// repository.ut.ac.id/4670/1/PANG4411-M1.pdf $\quad$ [n
Bahasa Indonesia].

Arampath, P.C. and Dekker, M. (2019). Bulk storage of mango (Mangifera indica L.) and pineapple (Ananas comosus L.) pulp: effect of pulping and storage temperature on phytochemicals and antioxidant activity. Journal of the Science of Food and Agriculture, 99(11), 5157-5167. https:// doi.org/10.1002/jsfa.9762

Gagnon, M., Savard, P., Rivière, A., Lapointe, G. and Roy, D. (2015). Bioaccessible antioxidants in milk fermented by Bifidobacterium longum subsp. longum strains. BioMed Research International, 2015, 169381. https://doi.org/10.1155/2015/169381

Kusumawati, I., Purwanti, R. and Afifah, D.N. (2020). Analisis Kandungan Gizi dan Aktivitas Antioksidan pada Yoghurt dengan Penambahan Nanas Madu (Ananas Comosus Mer.) dan Ekstrak Kayu Manis (Cinnamomum burmanni). Journal of Nutrition College, 8, 196-206. https://doi.org/10.14710/ jnc.v8i4.25833 [In Bahasa Indonesia].

Levy, E., Delvin, E., Marcil, V. and Spahis, S. (2020). Can phytotherapy with polyphenols serve as a powerful approach for the prevention and therapy tool of novel coronavirus disease 2019 (COVID-19)? American Journal of Physiology - Endocrinology and Metabolism, 319(4), E689-E708. https:// doi.org/10.1152/ajpendo.00298.2020

Lisdawati, V. and Kardono, L.B.S. (2006). Aktivitas Antioksidan Dari Berbagai Fraksi Esktrak Daging Buah dan Kulit Biji Mahkota Dewa (Phaleria macrocarpa). Media Penelitian dan Pengembangan Kesehatan, 16(4), 161424. [In Bahasa Indonesia].

Maldonado-Celis, M.E., Yahia, E.M., Bedoya, R., Landázuri, P., Loango, N., Aguillón, J., Restrepo, B. and Guerrero Ospina, J.C. (2019). Chemical Composition of Mango (Mangifera indica L.) Fruit: Nutritional and Phytochemical Compounds. Frontiers in Plant Science, 10, e01073. https:// doi.org/10.3389/fpls.2019.01073 [In Bahasa Indonesia].

Manning, J., Mitchell, B., Appadurai, D.A., Shakya, A., Pierce, L.J., Wang, H., Nganga, V., Swanson, P.C., May, J.M., Tantin, D. and Spangrude, G.J. (2013). Vitamin C promotes maturation of T-cells. Antioxidants and Redox Signaling, 19(17), 20542067. https://doi.org/10.1089/ars.2012.4988 
Mantik, K.E.K., Nurkolis, F., Mayulu, N., Kurniatanty, I., Widowati, E., Tanner, M.J. and Hardinsyah. (2021) Functional sugar from mango (Mangifera indica) rich in antioxidants and polyphenols potential for antidiabetic. Annals of the Romanian Society for Cell Biology, 25(1), 2545-2553.

Nurkolis, F., Surbakti, F.H., Sabrina, N., Azni, I.N. and Hardinsyah, H. (2020). Mango Sugar Rich in Vitamin C: A Potency for Developing Functional Sugar Rich in Antioxidants. Current Developments in Nutrition, 4(Supplement 2), 765-765. https:// doi.org/10.1093/cdn/nzaa052 034

Pitsillou, E., Liang, J., Ververis, K., Lim, K.W., Hung, A. and Karagiannis, T.C. (2020). Identification of Small Molecule Inhibitors of the Deubiquitinating Activity of the SARS-CoV-2 Papain-Like Protease: in silico Molecular Docking Studies and in vitro Enzymatic Activity Assay. Frontiers in Chemistry, 8, 623971. https://doi.org/10.3389/ fchem.2020.623971

Selibata, P.P., Smith, A. and Sinay, H. (2017). Perbedaan Kadar Vitamin C dan Lama Fermentasi Terhadap Yoghurt Dengan Penambahan Sari Buah Sirsak (Annona Muricata L). BIOPENDIX: Jurnal Biologi, Pendidikan Dan Terapan, 4(1), 44-47. https:// doi.org/10.30598/biopendixvol4issue1page44-47 [In Bahasa Indonesia].

Suhail, S., Zajac, J., Fossum, C., Lowater, H., McCracken, C., Severson, N., Laatsch, B., Narkiewicz-Jodko, A., Johnson, B., Liebau, J., Bhattacharyya, S. and Hati, S. (2020). Role of Oxidative Stress on SARS CoV (SARS) and SARSCoV-2 (COVID-19) Infection: A Review. The Protein Journal, 39(6), 644-656. https:// doi.org/10.1007/s10930-020-09935-8

Taslim, N.A., Rasyid, H., Atmanegara, M.K., Angriavan, S. and Amelia, R. (2020). Effect of Chocolate Soybean Drink on Nutritional Status, Gamma Interferon, Vitamin D, and Calcium in Newly Lung Tuberculosis Patients. Open Access Macedonian Journal of Medical Sciences, 8(T2), 210-214. https:// doi.org/10.3889/oamjms.2020.5233 